\title{
The Implementation of Environment Communication in Maintaining the Cleanliness of Cisadane River (Case Study in Government and Environment Department of Tangerang City)
}

\author{
Meisyanti ${ }^{1}$, Khina Januar Rahmawati ${ }^{2}$ \\ \{meisyanti.hutagaol@gmail.com ${ }^{1}$,khina.januar@gmail.com² ${ }^{2}$ g \\ Universitas Persada Indonesia YAI ${ }^{12}$
}

\begin{abstract}
Environment become a fundamental essential matter in the life, but not all of humans being can maintain the environment so that the pollution is occurred. One of some pollutions which is occurred in Indonesia water pollution in Cisadane River. A river that flows from Bogor City (West Java) to Tangerang Regency (Banten). Tangerang City as one of the cities flown by the Cisadane River and has the responsibility in keeping the Cisadane River clean. To implement environmental communication means disseminating environmental information, empowering the community to resolve various conflicts about the environment which in turn are expected to continue to preserve the environment. This research use case study method be reviewed features transformational communication (multi-level component) application by data collecting method is observation and interview to Government and Environment Department of Tangerang City. The environmental communication carried out by the Tangerang City Government and the Tangerang City Environment Department are reviewed by the implementation of transformational communication features (multi-level components) both media, information, education and social mobility components. There is also a need for awareness of the public and other stakeholders in maintaining the cleanliness of the Cisadane River and the need for synergy between the regional and provincial governments that flows through the Cisadane River.
\end{abstract}

Keywords: Implementation, Environment Communication, Cisadane River

\section{Introduction}

Communication is not more than the exchange of information in the high meaningful, not only as the form of interaction of human being, but also the nature environment and the culture social. Communication which is occurred between humans and the surrounding environment is called communication from the environment. Environmental communication is important for the survival of every living system, whether it is an organism, an ecosystem or a social system. Environmental communication also adheres to the principle that the goal of human communication is mutual understanding. In the environmental program agenda, communication should not only be viewed as an instrument or tool to support the implementation of environmental management, but rather become an integral part of environmental management itself. This means that the communication components of 
environmental management will face many problems which are quite crucial. In the level of cognitive, environment and the communication between human being especially have the meaning about the ability to act in contexts of the sustainability of habitat and also habitus, as the communities that attach the meaning in the long term [1] and environmental science integrate the easier system which would be understandable more easily, therefore it can be communicated by current communication methods [2].

Environment communication is the usage of approach, principle, strategy and public participation, also the implementation of program which is appointed in reaching the continuity of environment. In summary, environmental communication is an exchange of good information that is considered both in the form of knowledge and environmental policy [3]. In the practical sphere, communication can be done in a smart, sensitive, comprehensive and functional manner to encourage knowledge, awareness and participation of the community in maintaining the living environment. People participation are really needed, as the statement Jasanoff \& Wynee [4] said: "When individuals are provided with full information regarding a particular risk, and are then included in the development of responses to it, they are much more likely to engage in taking action than if given only limited information or responsibility". Meanwhile, the environmental communication program to build active participation in its implementation is with the support of policies and strategies created by the government and non-governmental organizations that are concerned about environmental problems. In order to achieve awareness and implementation of environmental communication, the government and non-governmental organizations can use one of the components from the transformational communication that is multilevel component, consists of media, information, education, and social mobilization. These four components need to be implemented in synergy ways so it will produce the effective communication.

To discuss the problem of implementation means to observe how far the policy operate after it were formulated and be done so that the function of implementation which is to form a relation that reach the target and object of public policy can be realized as target or object or the final results of activities carried out by the government. Of course, the government, as well as making policies, must also carry out an analysis related to the environmental impact on society, one of it is environmental pollution. Environmental pollution is a common problem, which is increasingly important to solve, because it involves safety, health and life together. Anyone can participate to solve this environmental pollution problem. Starting in the smallest environment, by its selves, to the wider environment.

In this research the meaning of environment pollution is the pollution of Cisadane River. The Cisadane River in Tangerang City is the main source of raw water for PDAM Kota Tangerang which is used to provide clean water for the Tangerang area. Based on research results from the Japan International Cooperation Agency (JICA), in collaboration with the Tangerang City Regional Environment Department (BLHD) in 2012, 84\% of the river water is contaminated with domestic waste, $14 \%$ was contaminated with waste from industries that did not have a wastewater treatment plant (IPAL), while the remaining $2 \%$ came from other waste pollution [5]. This pollution can make the river has a decreasing quality, as Jiao Ding, et al said that the decreasing of river quality is the impact of human being activities which do not care about the environment and not pay attention about the sustainable development principles [6].

One of the water pollution cause are Garbage, toxic and danger waste (B3). This problem is related to population increase, development and industrialization, the lifestyle and consumption patterns of the community. As a result, the volume, type and characteristics of 
solid waste and waste will increase every year. The cases of garbage and waste pollution are currently framing the Cisadane River Basin, Tangerang Regency, Banten Province. Cisadane River is a watershed area (DAS) that crosses several regencies and cities in West Java and Banten. Based on the results, the total area of the Cisadane watershed area is 161,147 hectares, of which 58,905 hectares are protected areas and 102,242 hectares non-protected areas [7].

Tangerang City become one of some territories that be flown by Cisadane River, which is of course also a concern for the Tangerang City Government including other agencies related to handling the Cisadane River. The government and certain agencies become one of the stakeholders who contribute in maintaining the cleanliness of the Cisadane River. The importance of communication between these stakeholders can certainly help to avoid further water pollution in the Cisadane River. Of course, communication that can be used is environmental communication, which is the use of communication approaches, principles, strategies and techniques for environmental management and protection. Implementing environmental communication means disseminating information on the environment, empowering the community to preserve the environment that ends up being successful.

\section{Research Method}

This research used qualitative approach, which was characterized by substantially inductive and open-ended methods [8]. This study used a qualitative approach with descriptive types of research. The qualitative descriptive studies have as their goal a comprehensive summary of events in everyday terms of those events. Researchers conducting qualitative descriptive studies stay close to their data and to the surface of words and events [9]. The method used in this study is a case study, that is best defined as an intensive study of a single unit with an aim to generalize across a larger set of units. Case studies rely on the same sort of covariational evidence utilized in non-case study research [10]. The data collection technique in this study is an observation which is carried out on a number of media or other objects that are related to the research topic. In addition to that, interview techniques were also used with information from the Government and the Department of the Environment Tangerang City.

\section{Results and Discussion}

The existence of the Cisadane River, which is running from West Java Province to Banten Province, is a very important matter to pay attention to, of course, not to be separated from the Tangerang City Government. The existence of the Cisadane River has been widely used by the surrounding community as a source of life, one of it is water. Cisadane River water is the water resources for the people of Tangerang. Because of many people are using the Cisadane River, it becomes polluted from the factories and household's waste. In the year of 2020, the data obtained that Cisadane River pollution is in mild to moderate category, stated Mr M. Djarkasih as Chief of Environmental Quality Monitoring Section:

"There are 16 points that are monitored, the river drainage is medium polluted and the river basin is low polluted." 
The city of Tangerang is one of the areas drained by the Cisadane River, which of course is also a concern for the Tangerang City Government, including other agencies related to handling the Cisadane River. The government and related Departments are certainly one of the stakeholders who have contributed to maintaining the cleanliness of the Cisadane River. The importance of communication between these parties can certainly help to prevent water pollution in the Cisadane River from happening again. Of course, in this case the communication that can be used is environmental communication, namely the use of approaches, principles, strategies and communication techniques for environmental management and protection.

From the data that has been analyzed, environmental communication in order to maintaining the cleanliness of the Cisadane River has been carried out by related parties that is the Government of the City of Tangerang and the City of Tangerang Environmental Management Department. As we all know, Tangerang City was awarded the Adipura Cup and Nirwasita Tantra in early 2019, specifically for the Tangerang City Adipura Cup, it has been awarded from 2011 to 2017. Departing from this, it can be seen that the Tangerang City Government and the Environment Department and other parties related has concerned to pay attention to environmental aspects of life including the cleanliness of the Cisadane River. From the observations made by researchers, it can be seen that the Cisadane River in the Tangerang City is quite clean and well maintained, if there are rubbish then there will be parties who then pick them up from the side of the related service or environmental lovers' community around the Cisadane River.

In its implementation, it can be seen that from the multi-level aspect of transformation communication (multi-level component). The first component is media, giving messages to maintaining environment and the Cisadane River cleanliness are using all media both conventional and new media. This is like what Mr. Mualim as a Chief of Public Information and Communication Dissemination

"All media are used including traditional face-to-face interaction. We use all the media to let the people who are not familiar with social media get information"

The conventional media used by the Tangerang City Government is Benteng newspaper which is printed and then distributed to the public, face to face with the surrounding community, even though in this pandemic face to face with the community is facilitated by carrying out webinars. The Tangerang City Environmental Department itself uses more faceto-face media to be able to communicate with the people of Tangerang City, because it is felt more effective, this was stated by Mr. Djarkasih :

"In my opinion, direct meeting is more effective. There are things that can be done by online, but in my opinion, it is better to meet directly. We visit to the location to give direction, guidance and give workshops to them so that the community know more. Not all of them are tech wavy. If we do the coaching through talks and conversation, they can try directly and we also get the social interaction."

This is suitable with the Newig,et al which stated face-to-face, but not mere two-way, communication appears to positively influence the ecological standard of decisions [11]. Face to face communication still become the effective communication especially for the society who still not able to use the technology yet. The Tangerang City Environmental 
Department also cooperate with Tangerang Kominfo Government to use Benteng newspaper as a distributor of information, and also use brochures to give away to the society. While the new media used are websites and social media. Website through www.tangerangkota.go.id, www.diskominfo.tangerangkota.go.id, or www.dislh.tangerangkota.go.id while social media through Facebook, Twitter, Instagram and Youtube.

In each website and social media there are variety of information, news and invitations about the environment. Apart from that, the Tangerang City Government, besides printing Benteng Newspapers distributed to the public, also made a digital version of Kota Tangerang e-Paper consisting of Benteng City, Live Magazine and Bulletin canals. For Youtube channel, Tangerang City Government has an account Kota Tangerang. There is also Tangerang City Government application portal "Tangerang Live". One of the features that can be used by the community is to report if there is garbage or other things that damage the environment, including if there is pollution in the Cisadane River, called LAKSA (Layanan Aspirasi Kotak Saran Anda). LAKSA is a communication media that functions to receive reports from incoming public so that it can be responded quickly by the relevant Department. With this feature, the community can easily report if there is a problem, via LAKSA, after that it will be followed up by the parties concerned. LAKSA is not specifically for environmental pollution but this portal is one form of media that can be used by the public to directly provide reports or advice to the government or other parties.

Basically using two medias because not every people can use digital, as Murin, at all research, said that level of education is important in green marketing enlightenment, where information are effective in secondary and higher educated members of society [12]. It can be deniable that there is education factor which can affected society to access media technology and to determine whether those communication are effective or not. New media can be the easy way to use in this era, however as Ahmad research, et all that the traditional media such as television and newspaper can also be effectively used to deliver environmental information [13]. Media becomes an important component to implement environmental communication, the media becomes an intermediary for communicators in delivering messages to the communicant. In the use of this media also requires synergy between several parties which is also one of the features of transformational communication.

The next component in multi-level transformational communication is information, from research it is known that the information or messages delivered are socialization or persuasive messages so that the community can contribute in maintaining the cleanliness of the Cisadane River and the environment of Tangerang City. This is one example of the application of environmental communication where communication should be able to generate community participation and empower people to be active in environmental matters. One of the problems faced by the City of Tangerang is waste management, although there has been a ban on the disposal of garbage to the Cisadane River in the City of Tangerang, but there are still parties who dump garbage into the Cisadane River, not only garbage but also domestic and factory waste. To overcome this, the Tangerang City Government and the Tangerang City Environment Department always appeal by sending messages both an invitation and also rewards to the people of the City of Tangerang. The message contained so that the community can sort out household waste so there is no accumulation of garbage in the Rawa Kucing landfill that can narrow the capacity of it, this is certainly also one way so that the habits of the people who often throw garbage into the river will not repeated again. Inorganic waste Households can be managed and then recycled into useful items, while organic can be used as fertilizer for plants. 
In addition, there are also messages that are rewarded by using the term "Sedekah Sampah" in which after being sorted, inorganic waste can be donated to the Tangerang City Environment Department and even the garbage can be picked up by the Environmental Service Department. The proceeds from the alms were delivered to the Tangerang City Baznas then distributed to the education fund for underprivileged students in Tangerang City schools. Not only that the Tangerang City Government and the Department of the Environment also gave a message that the results of the waste can be turned into money, at least it can pay cleanliness fees.

The essence of the rewarded is a message that is used quite often so that the community can move and be happy in carrying out any program from the Government and the Department of the Environment. It is going well with another research which stated that information component or messages can become the basic of community behavior and the messages can make the society become aware about the consequences they will get [14]. This message component has a purpose so that those who receive the message can be knowing, understanding so that they can carry out what is conveyed by the message sender, so that it can be become a process-oriented feature in Transformational communication.

Next component is education, in this component the communication carried out by the Tangerang City Government and the Department of the Environment is to provide environmental management socialization to the community, Islamic boarding schools, as well as to the managers of the City of Tangerang Garbage Bank. The aim is to educate the wider community about the importance of maintaining environmental cleanliness, waste management and the problems that will arise from waste. In addition, there is also coaching in the form of village programs and community service with the community. This education is not only done directly but also through existing media, one of it is on Instagram (a)dislh tng which besides posting about the City of Tangerang's Environmental Service activities also posting information in the form of pictures and text to educate its followers in protecting the environment. In providing education there are several programs carried out by the Tangerang City Environment Department, this was conveyed by Mr. Djarkasih :

"A program that is being implemented is a 'Kampung Iklim'. It contains three programs. The first one is 'Sedekah Air', a community effort to reverse the runoff position of water into the ground in order to prevent flooding. The second is 'Sedekah Sampah", an efforts to reduce waste at the source, waste that has economic value can be utilized by residents so that not all of them enter the landfill. The third is 'Sedekah Oksigen", which is through tree planting, where the Department of the Environment plants the seeds and when they are 50 $\mathrm{cm}$ high, the tree will be distributed to the local people."

Besides working on the above programs as a form of education to the community and schools, the Tangerang City Environmental Department, in the midst of the 19th Covid pandemic, continues to provide education to the community by group and conducting webinars, live on Instagram and Youtube. We all need a broader understanding of what we are about as environmentally-concerned citizens and educators: reconstructing the larger lifeworld in a way more connected to and consistently engaged with the world more than human being. School have a role to play within this reconstruction, but the essential process is much larger and must engage all of us [15]. Education to the community, schools and Islamic boarding schools are expecting to be able to form new habits so that they can be applied well, and can be passed on to other family members so that hopefully all citizens of Tangerang City can apply what is conveyed in socialization or coaching. 
The final component in multi-level is social mobilization which can be feature including in transformational communication. It is done by using interpersonal communication channels, where all this communications can be used to give a positive contribution to understanding, as well as to perpetuating some popular misconceptions [16]. It founded that a person's social network can have a significant effect on whether or not individuals can take a protective action or not [17]. Mobilization have become a part that must be done to make society take action to maintain environment. In this case the Tangerang City Government in implementing social mobilization prefers to empower opinion leaders such as the RT Chairperson, RW Chairperson and the environmental community as explained by $\mathrm{Mr}$. Mualim:

"Let's just direct it to the local, mingle with them, involving the RT RW, the community is more effective than just appointing someone to be a garbage ambassador and then he becomes our pawn because it's not massive enough."

The opinion from them is expected to be able to move the community become more aware and take actions to protect the environment, including to maintain the cleanliness of the Cisadane River. From their opinion, the more intimate interpersonal communication can actually be formed so that the process of influencing can occur more quickly because usually opinion leaders are people who can form public opinion so that people who follow them will do what they say. The Department of the Environment in this social mobilization component uses environmental cadres selected from members of the surrounding community. In addition, the Tangerang City Government has also several times empowered public figures residing in Tangerang or instructors who are experts in environmental matters to be able to provide socialization or also to educate the public about the environment. This component of social mobilization is certainly expected to be able to influence the community and empower the community in maintaining and preserving environmental cleanliness. It is hoping that society can be collectively and independently capable to do in mobilization have given.

In the implementation of environmental communication conducted by the City of Tangerang, indeed takes a long time so that all communities and other stakeholders can be aware and participate in maintaining environmental cleanliness, especially in this case, the cleanliness of the Cisadane River. But it cannot be denied that the role of other stakeholders also needs to be empowered and asked for their opinions. The role of the community, the private sector, the community, and NGOs both in the City of Tangerang and other areas that are flowing by the Cisadane River need to be increased. The Coordination between regions is very important considering the Cisadane River stretches from Bogor (West Java) to Banten, especially regarding the handling of rubbish and domestic waste. It needs to be handling from upstream to downstream so that the Cisadane River can keep well maintained and preserved. 


\section{Conclusions}

Based on data analysis, it can be concluded that the environmental communication of the Tangerang City Government and the Tangerang City Environment Department in order to maintain the cleanliness of the Cisadane River have been implemented both from the media component, information component, education component and social mobilization component. Where there is better behavior in maintaining and preserving the cleanliness of the Cisadane River, which certainly requires a fast time, so the Tangerang City Government and the Environment Department must continue to carry out environmental communication appropriately and be able to participate involving other stakeholders, so that the cooperation can be established and each stakeholder has an awareness of the same sense of responsibility. In addition, there still need for strong synergy and coordination between areas crossed by the Cisadane River, because the problem of Cisadane river cannot be resolved by one of the cities or regencies alone, it needs cooperation and joint responsibility.

\section{Acknowledgement}

The researcher would like to thank Kementerian Riset dan Teknologi / Badan Riset dan Inovasi Nasional (RISTEK-BRIN) Republik Indonesia who has given fund to this research and to every resource person and community members of RW.03 Kelurahan Karawaci who were willing to provide information for the implementation of this research.

\section{References}

[1] P. Bourdieu, "The Logic of Practice," Stanford Univ. Press, p. 154, 1992.

[2] T. Seebohm, "Hermeneutics. Method and Methodology. In: Contributions to Phenomenology. 50th Edition," Springer, p. 450, 2004.

[3] A. Flor and H. Cangara, Komunikasi Lingkungan: Penanganan Kasus-Kasus Lingkungan Melalui Strategi Komunikasi. Jakarta: Prenadamedia Group, 2018.

[4] R. J. Brulle, "From environmental campaigns to advancing the public dialog: Environmental communication for civic engagement," Environ. Commun., vol. 4, no. 1, pp. 82-98, 2010, doi: $10.1080 / 17524030903522397$

[5] M. Dawud, I. Namara, N. Chayati, and F. M. L. Taqwa, "Analisis Sistem Pengendalian Pencemaran Air Sungai Cisadane Kota Tangerang Berbasis Masyarakat," Jurnal.Umj.Ac.Id/Index.Php/Semnastek, pp. 1-8, 2016.

[6] J. Ding, Y. Jiang, L. Fu, Q. Liu, Q. Peng, and M. Kang, "Impacts of land use on surface water quality in a subtropical river basin: A case study of the dongjiang river basin, Southeastern China," Water (Switzerland), 2015, doi: 10.3390/w7084427.

[7] H. Harimurti, S. Solichin, A. F. Ramly, and H. Subroto, "Analisis Kawasan Lindung DAS Cisadane-Angke-Ciliwung," Jakarta, 2007.

[8] J. A. Maxwell and L. E. Reybold, "Qualitative Research," in International Encyclopedia of the Social \& Behavioral Sciences: Second Edition, 2015

[9] M. Sandelowski, "Whatever happened to qualitative description?," Res. Nurs. Health, 2000, doi: 10.1002/1098-240x(200008)23:4<334::aid-nur9>3.0.co;2-g.

[10] J. Gerring, "What is a case study and what is it good for?," Am. Polit. Sci. Rev., 2004, doi: $10.1017 / \mathrm{S} 0003055404001182$.

[11] J. Newig and O. Fritsch, "Environmental governance: Participatory, multi-level - And effective?," Environ. Policy Gov., 2009, doi: 10.1002/eet.509.

[12] I. Murin, I. Marková, J. Zelený, and J. Jad'ud'ová, "Green Marketing as a Tool Influencing Consumerś Behavior: Slovak Case Study of Regional Mark Preference," Procedia Econ. Financ., 2015, doi: 10.1016/s2212-5671(15)01628-7. 
[13] J. Ahmad, S. Md. Noor, and N. Ismail, "Investigating students' environmental knowledge,attitude,practice and communication," Asian Soc. Sci., 2015, doi: 10.5539/ass.v11n16p284.

[14] S. Dolnicar, A. Hurlimann, and B. Grün, "Water conservation behavior in Australia," J. Environ. Manage., 2012, doi: 10.1016/j.jenvman.2012.03.042.

[15] E. E. Communication, "Environmental Education Communication," Environ. Educ., 1996.

[16] K. R. Stamm, F. Clark, and P. R. Eblacas, "Mass communication and public understanding of environmental problems: The case of global warming," Public Underst. Sci., 2000, doi: 10.1088/0963-6625/9/3/302.

[17] T. Haer, W. J. W. Botzen, and J. C. J. H. Aerts, "The effectiveness of flood risk communication strategies and the influence of social networks-Insights from an agent-based model,” Environ. Sci. Policy, 2016, doi: 10.1016/j.envsci.2016.03.006. 